\title{
PERMOHONAN PAILIT OLEH KONSULTAN KEPADA PT. PRUDENTIAL LIFE ASSURANCE
}

\author{
J.B. Budhisatrio, Dhaniswara K Harjono, Binoto Nadapdap \\ Universitas Kristen Indonesia (UKI) Jakarta, Indonesia \\ Email: budhisatrio@gmail.com, dhaniswara.harjono@uki.ac.id, \\ binotonadapdap@ymail.com
}

\begin{tabular}{l}
\hline INFO ARTIKEL \\
\hline Diterima \\
25 Oktober 2021 \\
Direvisi \\
05 November 2021 \\
Disetujui \\
15 November 2021 \\
\hline Kata Kunci : \\
kepailitan; \\
perusahaan \\
asuransi; Otoritas \\
Jasa Keuangan \\
(OJK).
\end{tabular}

ABSTRAK

Penelitian Penyelesaian Utang melalui Kepailitan (Studi Kasus Pada Putusan Mahkamah Agung Tentang PT. Prudential Life Assurance) dilakukan untuk mengetahui apakah dasar pertimbangan utama yang dipergunakan oleh Majelis Hakim untuk memutus permohonan kepailitan di Mahkamah Agung Republik Indonesia dalam putusan Nomor : 08/K/N/2004 dan Kewenangan Menteri Keuangan yang dapat mempailitkan Perusahaan Asuransi dapat mengakibatkan Perusahaan Asuransi Kebal Pailit. Kasus ini bermula dari perjanjian keagenan antara PT. Prudential dan Lee Boon Siong. Akhirnya Prudential memutuskan perjanjian sepihak karena Lee Boon Siong dianggap telah melanggar perjanjian keagenan. Penelitian ini adalah sebuah penelitian yuridis normatif, penelitian yang mengutamakan penelitian kepustakaan dan dokumen-dokumen untuk memperoleh data sekunder. Pendekatan normatif dalam penelitian ini dengan kaidah-kidah hukum yang berkaitan dengan masalah penyelesaian utang dalam kepailitan, sedangkan pendekatan yuridis digunakan dalam mengadakan analisa hukum terhadap fakta-fakta hukum untuk selanjutnya digunakan dalam permasalahan-permasalahan yang terkait dengan masalah Penyelesaian Utang melalui Kepailitan. Hasil penelitian menunjukkan bahwa : Putusan No. 13/PAILIT/ 2004/PN.NIAGA.JKT.PST jo. Putusan Nomor : 08/K/N/2004 telah membawa PT. Prudential Life Assurance kepada Kepailitan yang dimohonkan oleh Konsultan Lee Boon Siong, sehingga dengan peristiwa ini menyebabkan UU No.4/1998 tentang Kepailitan mengalami perubahan menjadi UU No.37 Tahun 2004 (UUK-PKPU), dimana kewenangan pengajuan permohonan Kepailitan bagi perusahaan asuransi tidak lagi diajukan oleh Kreditor, namun berada di tangan Menteri Keuangan. Namun dalam perkembangan selanjutnya setelah berlakunya UU No. 40 Tahun 2014 tentang Perasuransian (UU Perasuransian), permohonan Pernyataan Kepailitan dan PKPU terhadap perusahaan asuransi beralih dari kewenangan Menteri

How to cite:

E-ISSN:

Published by:
Budhisatrio, J. B., Dhaniswara K Harjono, \& Binoto Nadapdap. (2021) Permohonan Pailit oleh Konsultan Kepada PT. Prudential Life Assurance. Jurnal Syntax Admiration 2(11). https://doi.org/10.46799/jsa.v2i11.337

2722-5356

Ridwan Institute 
Keuangan kepada Otoritas Jasa Keuangan (OJK).

\begin{abstract}
Research on Debt Settlement was conducted to find out whether the basic considerations used by the Panel of Judges to decide on a bankruptcy application at the Supreme Court of the Republic of Indonesia in the decision Number: 08/K/N/2004 and the Authority of the Minister of Finance which may bankrupt an Insurance Company can result in an Insurance Company Invulnerable to Bankruptcy. . This case stems from an agency agreement between PT. Prudential and Lee Boon Siong. Finally, Prudential terminated the agreement unilaterally because Lee Boon Siong was deemed to have violated the agency agreement. This research is a normative juridical research, research that prioritizes literature and documents research to obtain secondary data. The normative approach in this study uses legal principles related to settlement problems in bankruptcy, while the juridical approach is used in legal analysis of legal facts to be further used in problems related to the problem of Debt Settlement through Bankruptcy. The results showed that: Decision No. 13/PAILIT/2004/PN.NIAGA.JKT.PST jo. Decision Number : 08/K/N/2004 has brought PT. Prudential Life Assurance to Bankruptcy which was requested by Consultant Lee Boon Siong, so that with this incident caused Law No. 4/1998 concerning Bankruptcy to be changed to Law No. 37 of 2004 (UUK-PKPU), where the filing of bankruptcy petitions for insurance companies is no longer submitted by the Creditor, but is in the hands of the Minister of Finance. However, in subsequent developments after the enactment of Law no. 40 of 2014 on Insurance (Insurance Law), applications for Bankruptcy Statements and PKPU against insurance companies are transferred from the authority of the Minister of Finance (OJK).
\end{abstract}

Keywords :

bankruptcy;

insurance

company; financial services authority (OJK).

\title{
Pendahuluan.
}

Di era globalisasi dan informasi yang demikian cepat sekarang ini, kebutuhan akan perangkat regulasi di bidang perekonomian yang dapat menunjang iklim berinvestasi sangatlah penting. Ketentuan perundang-undangan di bidang ekonomi selayaknya dibuat sedemikian rupa agar dapat menciptakan iklim investasi yang positif yang pada akhirnya berdampak pada meningkatnya pertumbuhan ekonomi bangsa. Produk hukum nasional yang menjamin kepastian, ketertiban, penegakan dan perlindungan hukum yang berintikan keadilan dan kebenaran diharapkan mampu mendukung pertumbuhan dan perkembangan perekonomian serta mengamankan dan mendukung hasil pembangunan nasional.

Salah satu harmonisasi integrasi hukum yang sangat penting adalah terkait kemudahan berusaha (ease of doing business), satu diantaranya adalah mengenai 
penyelesaian kepailitan yang diatur dalam Undang-Undang Nomor 37 Tahun 2004 tentang Kepailitan dan Penundaan Kewajiban Pembayaran Utang (UUK-PKPU), diundangkan dalam Lembaran Negara Republik Indonesia Nomor 131 tanggal 18 Oktober 2004.

Istilah kepailitan sering kali masih terasa awam bagi sebagian orang, walau istilah ini sering digunakan dalam dunia bisnis dan usaha. Kepailitan merupakan suatu proses penyelesaian sengketa bisnis melalui jalur litigasi yaitu melalui Pengadilan Niaga. Sebelum diundangkannya UUK -PKPU, kepailitan diatur dalam Staatsblad 1905:217, Staatsblad 1906:348 tentang Faillissement Verordening (Undang-undang tentang Kepailitan) yang kemudian diperbarui melalui Peraturan Pemerintah Pengganti UndangUndang Nomor 1 Tahun 1998 dan kemudian disahkan menjadi Undang-Undang Nomor 4 Tahun 1998 tentang Penetapan Peraturan Pemerintah Pengganti Undang-Undang Nomor 1 Tahun 1998 tentang Perubahan atas Undang-Undang tentang Kepailitan menjadi Undang-Undang.

Menurut Pasal 1 angka 1 UUK-PKPU, Kepailitan adalah sita umum atas semua kekayaan Debitur Pailit yang pengurusan dan pemberesannya dilakukan oleh Kurator di bawah pengawasan Hakim Pengawas sebagaimana diatur dalam Undang-Undang ini. Berdasarkan rumusan pengertian Kepalitan tersebut dapat disimpulkan bahwa inti dari kepailitan adalah sita umum atas kekayaan debitur pailit.

Di dalam dunia bisnis serta era global seperti sekarang ini kegiatan-kegiatan usaha tidak mungkin lepas dari berbagai masalah, sehingga suatu perusahaan tidak selalu berjalan dengan baik dan seringkali keadaan keuangannya sudah sedemikian rupa sehingga perusahaan tersebut tidak lagi sanggup membayar utang-utangnya. Dapat dikatakan bahwa kehidupan suatu perusahaan dapat saja dalam kondisi untung atau dalam keadaan rugi. Kalau dalam keadaan untung, perusahaan berkembang dan terus berkembang, sehingga menjadi perusahaan raksasa. Sebaliknya apabila perusahaan menderita kerugian, maka garis hidupnya menurun, jadi garis hidup suatu perusahaan pada suatu saat dapat naik dan pada saat lain menurun, begitu seterusnya, sehingga garis hidup perusahaan itu merupakan garis yang menaik dan menurun seperti grafik (Situmorang \& Soekarso, 1994).

Permohonan pernyataan pailit diajukan ke Pengadilan Niaga dan yang berhak mengajukannya antara lain adalah Kreditur, Debitur, Bank Indonesia, Menteri Keuangan, Badan Pengawas Pasar Modal (sekarang Otoritas Jasa Keuangan) dan Jaksa demi kepentingan umum. Permohonan pernyataan pailit yang telah diterima oleh Pengadilan akan diproses melalui sidang pemeriksaan dan selambat-lambatnya putusan pailit harus dibacakan 60 (enam puluh) hari setelah tanggal pendaftaran permohonan pernyataan pailit.

Kepailitan diawali dengan pengajuan permohonan pernyataan pailit dan akan menghasilkan sebuah putusan pailit. Dalam putusan pailit terdapat beberapa akibat hukum bagi debitur pailit, salah satunya berakibat pada kewenangan berbuat debitur pailit dalam bidang hukum harta kekayaan. Hal ini mengakibatkan kewenangan debitur menjadi sangat terbatas. Debitur pailit hanya dapat melakukan perbuatan yang dapat 
memberikan suatu keuntungan atau perbuatan yang dapat menambah jumlah harta kekayaan yang selanjutnya dijadikan sebagai boedel pailit.

Tetapi apabila perbuatan debitur pailit tersebut dimungkinkan akan mendatangkan kerugian atau dapat mengurangi harta pailit, kurator dapat meminta pembatalan perbuatan hukum yang telah dilakukan oleh debitur pailit. Pembatalan tersebut bersifat relatif, artinya hal itu hanya dapat digunakan untuk kepentingan harta pailit sebagaimana diatur dalam Pasal 41 UUK-PKPU. Tindakan yang dilakukan kurator untuk meminta pembatalan tersebut disebut dengan Actio Paulina. Selain untuk melindungi agar harta pailit tidak berkurang, pembatalan tersebut juga dilakukan untuk melindungi kepentingan kreditur agar tidak dirugikan.

Sebagaimana ketentuan yang diatur dalam Pasal 41 ayat (2) UUK-PKPU, bahwa : "Pembatalan tersebut hanya dapat dilakukan apabila dapat dibuktikan bahwa pada saat perbuatan hukum tersebut dilakukan, Debitur dan pihak dengan siapa perbuatan hukum tersebut dilakukan mengetahui atau sepatutnya mengetahui bahwa perbuatan hukum tersebut akan mengakibatkan kerugian bagi Kreditor".

UUK-PKPU juga mengatur mengenai perbuatan hukum satu pihak yang dilakukan oleh debitur pailit, yakni hibah yang diatur dalam Pasal 43 UUK-PKPU : "Hibah yang dilakukan Debitor dapat dimintakan pembatalan kepada Pengadilan, apabila Kurator dapat membuktikan bahwa pada saat hibah tersebut dilakukan Debitor mengetahui atau patut mengetahui bahwa tindakan tersebut akan mengakibatkan kerugian bagi Kreditor". Dari ketentuan tersebut dapat disimpulkan bahwa kurator tidak perlu membuktikan apakah penerima hibah mengetahui perbuatan hibah tersebut merugikan kreditur atau tidak, kurator hanya perlu membuktikan bahwa debitur dianggap mengetahui bahwa hibah tersebut merugikan kreditur dan apabila hibah tersebut dilakukan dalam jangka waktu 1 (satu) tahun sebelum putusan pernyataan pailit ditetapkan.

UUK-PKPU mengatur juga mengenai pembatalan pembayaran utang oleh debitur pailit karena adanya kecurigaan guna menguntungkan salah satu kreditur. Hal tersebut diatur pada Pasal 45 UUK-PKPU, yaitu : "Pembayaran suatu utang yang sudah dapat ditagih hanya dapat dibatalkan apabila dibuktikan bahwa penerima pembayaran mengetahui bahwa permohonan pernyataan pailit Debitor sudah didaftarkan, atau dalam hal pembayaran tersebut merupakan akibat dari persekongkolan antara Debitor dan Kreditor dengan maksud menguntungkan Kreditor tersebut melebihi Kreditor lainnya" (Kementrian Keuangan Republik Indonesia, 2020).

Penulis dalam penulisan ini akan membahas mengenai: Bagaimana Permohonan pailit oleh konsultan kepada PT. Prudential Life Insurance dan putusan pengadilan kepada kedua pihak?

Teori yang digunakan adalah teori teori keadilan yang dikemukakan oleh Nindyo Pramono dan Sularto, dalam bukunya yang berjudul "Hukum Kepailitan dan Keadilan Pancasila". Nindyo Pramono dan Sularto menjelaskan bahwa, keadilan dalam hukum selalu berkaitan antara hubungan orang dengan orang, dan bukan hanya individu saja. Bahwa dalam kepailitan asas keadilan mengandung pengertian bahwa ketentuan 
mengenai kepailitan dapat memenuhi keadilan bagi para pihak yang berkepentingan. Asas keadilan ini untuk mencegah terjadinya kesewenang-wenangan pihak penagih yang mengusahakan pembayaran atas tagihan masing-masing terhadap debitur, dengan tidak memperdulikan kreditor lainnya.

Adil berarti harus sama dan proporsional, adil berarti harus seimbang dan wajar, adil berarti harus memberikan jaminan atas tepenuhinya hak dasar, adil berarti harus melaksanakan hak dan kewajiban dalam undang-undang secara konsisten dan wajar, dan adil berarti harus aspiratif. Walaupun tujuan dari kepailitan adalah dalam rangka perlindungan kreditor, namun terdapat sejumlah pasal yang menurut Nindyo Pramono dan Sularto masih menimbulkan ketidakadilan bagi kreditor (khususnya kreditor lain/bukan kreditor pemohon kepailitan).

1. Pertama, kreditor hanya memiliki waktu terbatas untuk membatalkan kepailitan. Pasal 2 UUK-PKPU, menyatakan bahwa debitor yang mempunyai dua atau lebih kreditor dan tidak dapat membayar lunas sedikitnya satu utang yang telah jatuh waktu dan dapat ditagih, dinyatakan pailit dengan putusan Pengadilan, baik atas permohonan sendiri maupun atas permohonan satu atau lebih kreditornya. Ketentuan di dalam pasal ini pada dasarnya kurang melindungi kepentingan kreditor, terutama jika tanpa alasan yang cukup, debitur harus dinyatakan pailit oleh debitur sendiri atau pihak lain di luar kreditor, seperti Kejaksaan, Bank Indonesia, Kementerian Keuangan (Kemenkeu), Badan Pengawas Pasar Modal (sekarang Otoritas Jasa Keuangan), dan lain sebagainya. Selain itu, ketentuan ini juga kurang cukup melindungi kepentingan kreditor-kreditor lain (di luar pemohon pailit) jika kepailitan diajukan oleh kreditor.

2. Kedua, kreditor pemegang jaminan dibatasi dalam melakukan eksekusi atas objek jaminan. Sesuai dengan penggolongan kreditor menurut tingkatannya, maka kreditor separatis (istilah lain dari kreditor pemegang hak jaminan gadai, hipotik, fidusia, dan hak tanggungan), merupakan kreditor yang harus mendapatkan prioritas penuh terhadap harta debitur yang ada dalam penguasaanya atas dasar perjanjian penjaminan. Harta janinan harus disisihkan dari boedel pailit, mengingat harta tersebut hanya diperuntukkan untuk pemenuhan piutang-piutang pemegang jaminan (Nindyo Pramono \& Sularto, 2017).

Hukum kepailitan sudah ada sejak zaman Romawi. Kata "bangkrut", dalam bahasa Inggris disebut "bankrupt", berasal dari undang-undang Italia, yaitu banca rupta. Sementara itu, di Eropa abad pertengahan ada praktik kebangkrutan di mana dilakukan penghancuran bangku-bangku dari para bankir atau pedagang yang melarikan diri secara diam-diam dengan membawa harta para kreditor. Atau, seperti keadaan di Venetia (Italia) waktu itu, dimana banco (bangku) para pemberi pinjaman (bankir) saat itu sudah tidak mampu lagi membayar utang atau gagal dalam usahanya, dipatahkan atau dihancurkan.

Bagi negara-negara yang menganut tradisi common law, tepatnya pada tahun 1952 merupakan tonggak sejarah karena pada tahun tersebut hukum pailit dari tradisi hukum Romawi diadopsi ke negara Inggris. Hal tersebut ditandai dengan diundangkannya 
sebuah Undang-Undang yang disebut Act Against Such Persons As Do Make Bankrupt, yang menempatkan kebangkrutan sebagai hukuman bagi debitor nakal yang tidak mau membayar utangnya sekaligus berusaha menyembunyikan asset-assetnya. Undangundang ini memberikan hak-hak bagi kelompok kreditor yang tidak dimiliki oleh kelompok kreditor secara individual (Fuady, 1999).

Peraturan kepailitan di Indonesia termasuk dalam hukum dagang, meskipun tidak diatur secara eksplisit dalam Kitab Undang-Undang Hukum Dagang (KUHD). Peraturan mengenai kepailitan diatur dalam peraturan tersendiri, yaitu dalam "Faillissementsverordening" (Staatblad tahun 1905 Nomor 217 jo. Staatblad tahun 1906 Nomor 348), yang juga berlaku bagi golongan Cina dan Timur Asing (Purwosutjipto, 1988).

Pengajuan permohonan pailit terhadap perusahaan asuransi sudah terjadi di Indonesia sejak berdirinya Pengadilan Niaga. Perusahaan Asuransi, bila dianalogikan sama dengan Bank, juga berfungsi sebagai lembaga yang mengelola dana masyarakat dengan jumlah nasabah yang cukup besar. Oleh karenanya, proses kepailitan terhadap perusahaan asuransi menjadi perhatian pemerintah. Pemerintah memiliki kepentingan jika sudah menyangkut dana masyarakat.

Menurut Pasal 2 ayat (3), ayat (4) dan ayat (5)UUK-PKPU, bahwa ada syaratsyarat untuk mengajukan permohonan pailit terhadap debitor-debitor tertentu sebagaimana diatur dalam, sebagai berikut :

- Dalam hal Debitor adalah bank, permohonan pernyataan pailit hanya dapat diajukan oleh Bank Indonesia.

- Dalam hal Debitor adalah Perusahaan Efek, Bursa Efek, Lembaga Kliring dan Penjaminan, Lembaga Penyimpanan dan Penyelesaian, permohonan pernyataan pailit hanya dapat diajukan oleh Badan Pengawas Pasar Modal (sekarang OJK).

- Dalam hal Debitor adalah Perusahaan Asuransi, Perusahaan Reasuransi, Dana Pensiun, atau Badan Usaha Milik Negara yang bergerak di bidang kepentingan publik, permohonan pernyataan pailit hanya dapat diajukan oleh Menteri Keuangan.

Berdasarkan ketentuan tersebut, maka Perusahaan Asuransi merupakan bagian dari debitor tertentu yang bergerak di bidang publik, yang mana pengajuan pernyataan pailit hanya dapat diajukan oleh Menteri Keuangan. Bila Menteri Keuangan sudah mengajukan pernyataan pailit, Pengadilan Niaga harus mengabulkan permohonan pailit yang sebelumnya sudah memenuhi tiga unsur pernyataan pailit, menurut pasal 2 ayat (1) jo. pasal 8 ayat (4) UUK-PKPU, yaitu:

1. Ada dua atau lebih kreditor. Kreditor adalah orang yang mempunyai piutang karena perjanjian atau Undang-Undang yang dapat ditagih di muka pengadilan "Kreditor" di sini mencakup baik kreditor konkuren, kreditor separatis maupun kreditor preferen;

2. Ada utang yang telah jatuh waktu dan dapat ditagih. Artinya adalah kewajiban untuk membayar utang yang telah jatuh waktu, baik karena telah diperjanjikan, karena percepatan waktu penagihannya sebagaimana diperjanjikan, karena pengenaan 
sanksi atau denda oleh instansi yang berwenang, maupun karena putusan pengadilan, arbiter, atau majelis arbitrase; dan

3. Kedua hal tersebut di atas harus dapat dibuktikan secara sederhana.

Dalam pertimbangannya Majelis Hakim Mahkamah Agung (MA) berpendapat, bahwa pemohon tidak mempunyai legalitas dalam mengajukan permohonan. Sebagai perusahaan asuransi di bidang kerugian dan reasuransi kerugian, pengajuan permohonan pailit tunduk pada ketentuan khusus yang mengatur mengenai kepailitan perusahaan asuransi.

Sebagaimana Pasal 2 ayat (5) UUK-PKPU telah diatur "Dalam hal debitur adalah perusahaan adalah perusahaan asuransi, perusahaan reasuransi, danan pensiun, atau Badan Usaha Milik Negara yang bergerak di bidang kepentingan publik, permohonan pernyataan pailit hanya dapat diajukan oleh Menteri Keuangan." Pasal 20 ayat (1) UU No. 2 /1992 tentang Usaha Perasuransian menyebutkan bahwa "dengan tidak mengurangi berlakunya ketentuan dalam Peraturan Kepailitan, dalam hal terdapat pencabutan izin usaha sebagaimana dimaksud dalam Pasal 18, maka Menteri, berdasarkan kepentingan umum, dapat memintakan kepada Pengadilan agar perusahaan yang bersangkutan dinyatakan pailit".

Persetujuan dari Menteri Keuangan ini membatasi tindakan perusahaan asuransi yang telah dicabut izin usahanya dalam hal mengajukan permohonan pailit secara sukarela. Hal ini dilakukan Menteri Keuangan bertujuan demi mengedepankan kepentingan umum maupun sebagai perlindungan hukum bagi nasabah-nasabah perusahaan asuransi yang bersangkutan.

Sejak hadirnya UU No. 21/2011 tentang Otoritas Jasa Keuangan (OJK) yang fungsinya menyelenggarakan sistem pengaturan dan pengawasan yang terintegrasi terhadap keseluruhan kegiatan di dalam sektor jasa keuangan, dengan demikian kewenangan pengajuan pailit terhadap Perusahaan Asuransi, Perusahaan Asuransi Syariah, perusahaan reasuransi, dan perusahaan reasuransi syariah yang semula dilakukan oleh Menteri Keuangan berdasarkan Undang-Undang Nomor 37 Tahun 2004 tentang Kepailitan dan Penundaan Kewajiban Pembayaran Utang ("UU-KPKPU”) beralih menjadi kewenangan OJK berdasarkan UU Perasuransian. (BPLawyers 20 February, 2017).

Jika dibandingkan dengan perkara pailitnya Perusahaan Asuransi Jiwa Manulife Indonesia berdasarkan Putusan No. 10/Pailit/2002/PN.Niaga.Jkt.Pst jo.Putusan MA No. 021/K/N/2002dapat disimpulkan bahwa prosedur permohonan pailit terhadap PT.Asuransi Jiwa Manulife Indonesia tidak sesuai dengan UU No. 4 Tahun 1998 tentang Kepailitan khususnya Pasal 67 ayat (5) dan Pasal 70 serta tidak sesuai dengan ketentuan yang terdapat dalam Pasal 20 ayat (1) UU No. 2 Tahun 1992 tenntang Usaha Perasuransian, dimana yang memiliki wewenang untuk meminta pengadilan agar perusahaan asuransi dapat dipailitkan atas dasar kepentingan umum adalah Menteri Keuangan.

\section{Metode Penelitian.}


Penelitian yang akan dilakukan adalah penelitian hukum normatif. Penelitian hukum normatif terutama dilakukan untuk penelitian norma hukum dalam pengertian ilmu hukum sebagai ilmu tentang kaidah atau apabila hukum dipandang sebagai sebuah kaidah yang perumusannya secara otonom tanpa dikaitkan dengan masyarakat. Penelitian normatif yang didasarkan pada bahan hukum primer dan sekunder yaitu menginventarisasi peraturan-peraturan yang berkaitan dengan penulisan penelitian penulis.

Dalam penyusunan penelitian ini, sumber data yang digunakan adalah data sekunder yang terdiri dari bahan hukum primer, sekunder, dan tersier. Data sekunder adalah mencakup dokumen-dokumen resmi, buku-buku, hasil-hasil penelitian yang berwujud laporan dan sebagainya (Amiruddin \& Asikin, 2004). Bahan hukum primer yaitu bahan hukum yang terdiri dari peraturan perundang-undangan di bidang kepailitan menurut Pasal 1 angka 1 UUK-PKPU.

Bahan hukum sekunder yaitu bahan hukum yang memberikan penjelasan terhadap bahan hukum primer yakni hasil karya para ahli hukum berupa buku-buku, pendapatpendapat sarjana, yang berhubungan dengan pembahasan penelitian ini. Bahan hukum tersier atau bahan penunjang yaitu bahan hukum yang memberikan petunjuk atau penjelasan bermakna terhadap bahan hukum primer dan/atau bahan hukum sekunder yakni kamus hukum dan Kamus Besar Bahasa Indonesia. Sedangkan Pengumpulan data dilakukan dengan cara studi kepustakaan (library reasearch) yaitu serangkaian usaha untuk memperoleh data dengan jalan membaca, menelaah, mengklarifikasi, mengidentifikasi, dan dilakukan pemahaman terhadap bahan-bahan hukum yang berupa peraturan perundang-undangan serta buku-buku literatur yang ada relevansinya dengan permasalahan penelitian.

\section{Hasil dan Pembahasan.}

\section{Profil Perusahan.}

Didirikan pada tahun 1995, PT.Prudential Life Assurance (Prudential Indonesia) merupakan bagian dari Prudential plc, sebuah grup perusahaan jasa keuangan terkemuka di Inggris. Sebagai bagian dari Grup yang berpengalaman lebih dari 168 tahun di industri asuransi jiwa, Prudential Indonesia memiliki komitmen untuk mengembangkan bisnisnya di Indonesia. Sejak peluncuran produk asuransi terkait investasi (unit link) pertamanya di tahun 1999, Prudential Indonesia telah menjadi pemimpin pasar untuk kategori produk tersebut di Indonesia. Prudential Indonesia menyediakan berbagai produk dan layanan yang dirancang untuk memenuhi dan melengkapi setiap kebutuhan keuangan para nasabahnya di Indonesia. Prudential Indonesia juga telah mendirikan unit bisnis Syariah sejak tahun 2007 dan dipercaya sebagai pemimpin pasar asuransi jiwa syariah di Indonesia sejak pendiriannya. Sampai dengan 31 Desember 2019, Prudential Indonesia memiliki kantor pusat di Jakarta dan kantor pemasaran di Medan, Surabaya, Bandung, Denpasar, Batam dan Semarang. Sekitar 2 juta nasabah dilayani oleh lebih dari 260.000 tenaga pemasar berlisensi di 383 Kantor Pemasaran Mandiri (KPM) di 
seluruh nusantara termasuk Jakarta, Surabaya, Medan, Bandung, Yogyakarta, Batam, dan Bali. Prudential Indonesia terdaftar di dan diawasi oleh Otoritas Jasa Keuangan (OJK). Beberapa pencapaian bisnis kunci sampai 31 Desember 2019:

- Total pendapatan premi: Rp 25 triliun

- Total pendapatan kontribusi bruto: Rp3,7 triliun

- Total aset: Rp80,7 triliun

- Total dana kelolaan: Rp74,5 triliun

- Total klaim dibayarkan: Rp15,6 triliun

- Risk-Based Capital (RBC): 678\%. Lebih dari lima kali persyaratan minimum wajib dari pemerintah sebesar 120\% (prudential.co.id, 1995).

Citra Prudential di Inggris tidak diragukan lagi, merupakan perusahaan asuransi terbesar dan telah mengasuransikan ribuan jiwa dalam kecelakaan kapal Titanic. Nama Prudential sendiri memang sudah tidak asing lagi bagi masyarakat Indonesia, walau ada sebagian orang tidak tahu produk apa yang dijual oleh Prudential tetapi masyarakat selalu mengaku pernah mendengar nama tersebut melalui media massa.

Prudential juga mendapat predikat asuransi terbaik selama 5 tahun berturut turut (2002-2006) menurut majalah Investor yang beraset di atas 1 Triliun. Tetapi bagaimana citra Prudential di masyarakat Indonesia sendiri yang telah memandang asuransi sebagai image yang kurang baik? Di tengah - tengah ketidakpercayaan masyarakat terhadap perusahaan asuransi, tiba - tiba saja pada tanggal 24 April 2004 Prudential dinyatakan pailit oleh pengadilan Niaga pada Pengadilan Negeri Jakarta Pusat, karena ulah mantan agentnya. Prudential bukanlah satu-satunya asuransi yang pernah dipailitkan. Tetapi kepailitan Prudential lebih marak dan membuat mata publik terbelalak, karena Prudential merupakan sebuah perusahaan asuransi beraset Rp 1,5 triliun dengan kemampuan mengatasi kewajiban lebih dari dua kali, begitu mudahnya dipailitkan oleh beberapa pihak yang merasa dirugikan. Ketika masa pailit yaitu antara 24 April 2004 sampai dengan 7 Juni 2004 banyak nasabah Prudential yang panik dan menarik semua uang mereka, di situlah masa di mana Prudential kehilangan kepercayaan dari masyarakat.

\section{Kronologi Permohonan Pailit}

Kasus perjanjian kontrak seorang Konsultan Asuransi warga negara Malaysia dengan Perusahaan Asuransi PT. Prudential Life Assurance, menyusul permohonan pailit oleh konsultan tersebut sehingga oleh Pengadilan Niaga Jakarta Pusat. PT.Prudential Life Assurance dinyatakan pailit tanggal 23 April 2004. Keputusan ini tentunya mengagetkan semua pihak dimana kinerja dan keuangan PT. Prudential Life Assurance masih sehat. Sehingga permohonan Kasasi ke Mahkamah Agung pun diajukan oleh pihak Prudential. Tanggal 19 Mei 2004 Dewan Asuransi Indonesia meminta Mahkamah Agung mengabulkan permohonan kasasi Prudential. Akhirnya tanggal 7 Juni 2004, Mahkamah Agung mengabulkan permohonan kasasi Prudential dan menganulir putusan pailit Pengadilan Niaga pada Pengadilan Negeri Jakarta Pusat. Selain kasus ini terdapat beberapa kasus serupa yang akhirnya muncul perubahan terhadap UU Kepailitan No. 4 Tahun 1998. 
Pada tanggal 1 Juli 2000 Lee Boon Siong, warga negara Malaysia, bersama PT. Prudential menandatangani perjanjian kerjasama keagenan. Berdasarkan perjanjian tersebut, Lee wajib mengembangkan keagenan dan memasarkan produk asuransi PT. Prudential. Sebaliknya, perusahaan asuransi yang mulai beroperasi di Indonesia pada 1995 itu wajib membayar bonus atas prestasi yang dicapai Lee.

Pada tanggal 20 Januari 2004, PT. Prudential membatalkan perjanjian itu secara sepihak. Karenanya pada tanggal 7 April 2004 Lee mengajukan permohonan pailit perusahaan asuransi yang induknya didirikan di London, Inggris, pada tahun 1848 tersebut. Pengacara Lee, Lucas, menyatakan ada empat kewajiban PT. Prudential yang tidak dipenuhi. Mulai dari :

1. Tidak membayar biaya perjalanan sebesat Rp 130 juta,

2. Belum membayar bonus rekrutmen sebesar Rp 4,2 miliar,

3. Bonus konsistensi Rp 1,4 miliar, hingga jasa konsultasi keagenan senilai Rp 360 miliar.

4. Semua utang itu menjadi jatuh tempo karena dibatalkannya perjanjian.

Dari keempat kewajiban tersebut hanya satu yang disetujui dan dikabulkan oleh Pengadilan Niaga yaitu bonus konsistensi. Dan ini berakibat fatal, karena syaratsyarat dalam kepailitan terpenuhi (saat itu masih merujuk pada Undang-Undang No.4 Tahun 1998), yaitu adanya satu utang yang jatuh tempo dan dapat ditagih serta adanya minimal dua kreditor. Tak pelak tanggal 23 April 2004 majelis menyatakan PT.Prudential pailit. Putusan ini membuat kaget sekaligus menyulut kekecewaan Presiden Direktur PT Prudential saat itu, Charlie E Oropeza. Sebab perusahaan memiliki kondisi keuangan yang sangat kuat saat itu sehingga putusan itu sama sekali tidak berdasar. Pada saat itu Prudential memiliki 230 karyawan dan 8000 tenaga pemasaran. Per tanggal 31 Desember 2003, tingkat risk based capital-nya mencapai $225 \%$, jauh melampaui ketentuan Departemen Keuangan sebesar 100\%. Sementara itu, total pendapatan premi tumbuh $114 \%$ jika dibanding pada 2002, dari Rp 477 miliar menjadi lebih dari Rp 1 triliun. Efek ke Perusahaan Asuransi (KoranTempo, 2004).

Persyaratan kepailitan dibuat lebih sederhana supaya lebih mudah menjatuhkan pailit bagi perusahaan-perusahaan yang enggan melunasi hutang ataupun wanprestasi. Akibatnya, cukup banyak perusahaan mendapat putusan pailit, tak terkecuali perusahaan asuransi yang nyatanya bergerak di bidang kepentingan publik. Menyangkut perusahaan asuransi semenjak diberlakukannya UU No.4/1998 tercatat beberapa perkara kepailitan diputus Pengadilan Niaga Jakarta Pusat, antara lain Lee Boon Siong melawan PT. Prudential Life Assurance.

UU No.4/1998 banyak mendapat kritik karena memperlakukan perusahaan asuransi selaku debitor tidak sama dengan perusahaan yang bergerak di bidang kepentingan publik lainnya dalam hal pengajuan permohonan pailit. Kritik tersebut diakomodir dalam amandemen UU Kepailitan yang kemudian disahkan menjadi UU No. 37/2004 tentang Kepailitan dan Penundaan Kewajiban Pembayaran Utang (UUK-PKPU). Dalam UUK-PKPU terdapat ketentuan bahwa jika debitor adalah 
perusahaan asuransi atau reasuransi, maka pengajuan permohonan pailit dilakukan oleh Menteri Keuangan (Moneta, 2004).

Keadaan pailit atau bangkrut merupakan peristiwa yang bisa terjadi pada siapa saja. Mulai dari orang perorangan maupun badan hukum (legal entity). Di Indonesia, istilah 'pailit' ditujukan pada seseorang yang tidak lagi mampu membayar utangnya. Istilah 'pailit' kemudian menjadi istilah hukum ketika untuk pertama kalinya Indonesia memiliki undang-undang kepailitannya sendiri pada tahun 1998, yaitu Peraturan Pemerintah Pengganti Undang-Undang No. 1 tahun 1998 tetang Perubahan Atas Undang-Undang tentang Kepailitan, yang kemudian menjadi undang-undang berdasarkan Undang-Undang No. 4 Tahun 1998 dan kemudian diganti menjadi Undang-Undang No. 37 tahun 2004 tentang Kepailitan dan Penundaan Kewajiban Pembayaran Utang. (Selanjutnya disebut UU Kepailitan dan PKPU) (Ginting, 2018).

\section{Putusan Permohonan Pailit PT Prudential Life Assurance}

Skandal pailit PT. Prudential Life Assurance (Asuransi Prudential) yang diputus Pengadilan Niaga Jakarta Pusat pada tahun 2004 mengingatkan kita pada kasus pailit PT. Asuransi Jiwa Manulife Indonesia beberapa waktu lalu.

Putusan No. 13/PAILIT/2004/PN.NIAGA.JKT.PST yang dibacakan Majelis Hakim pada tanggal 23 April 2004 , dengan mengabulkan permohonan Lee Boen Siong (Pemohon) sebuah perusahaan konsultan asal Malaysia yang menandatangani perjanjian keagenan (Pioneering Agency Bonus Agreement) dengan Prudential (Termohon) telah mendapat reaksi yang cukup beragam dari berbagai kalangan.

Dalam sidangnya pada tanggal 23 April 2004, Majelis Hakim yang diketuai Putu Supadmi mengabulkan gugatan pailit Lee Boen Siong dengan alasan perusahaan asuransi yang berbasis di London, Inggris itu dianggap melakukan wanprestasi dan tidak memenuhi kewajiban pembayaran utang senilai Rp 1,43 miliar.

Selain Lee, Prudential juga dianggap lalai memenuhi kewajibannya kepada Hartono Hojana Rp 347 juta dan Budiman Rp 21 juta. Padahal, Prudential merupakan bagian dari Prudential Plc., sebuah perusahaan jasa keuangan internasional terkemuka di Inggris yang memiliki aset US\$ 300 miliar atau sekitar Rp 2,550 triliun. Selama beroperasi di Indonesia sejak 1995, kinerja perusahan ini cukup sehat dengan total kekayaan Rp 1,575 triliun, sedangkan jumlah kewajibannya Rp 1,373 triliun dengan RBC (risk base capital) atau solvabilitas 255 persen.

Karena itu, tuduhan wanprestasi terhadap Prudential tidaklah berbeda dengan Manulife, perusahaan asuransi terbesar yang berbasis di Kanada, itu karena menolak pembayaran dividen kepada PT.Dharmala Sakti Sejahtera Tbk. Rp 32,7 miliar yang merupakan salah satu pemegang saham terbesar di perusahaan itu.

Komposisi saham Dharmala dalam The Manufacturers Life Insurance Company Canada (Manulife) 40 persen atau setara dengan 1.800 lembar saham, Manulife 51 persen, dan International Finance Corporation 9 persen. Dalam kasus Manulife, permohonan pailit diajukan kurator Dharmala, Paul Sukran dan sempat menimbulkan berbagai argumentasi dan interpretasi dari kalangan praktisi hukum, 
khususnya menyangkut kewenangan kurator dalam memutuskan status dan aktivitas debitor dalam pailit atau tidak.

Lazimnya dalam berbagai kasus kepailitan, kurator secara profesional memegang peranan strategis dan sangat menentukan kelangsungan perkara yang dihadapi. Karenanya, hal yang terpenting menyangkut tugas dan tanggung jawab kurator adalah soal independensinya. Sejauh mana kurator berwenang melakukan recovery aset dalam upaya mengumpulkan dan memaksimalisasi nilai harta pailit untuk selanjutnya mengembalikannya kepada kreditor dari debitor pailit.

Skandal pailit Prudential menyangkut eksistensi dan kredibilitas kurator. Menurut Ricardo Simanjuntak, kuasa hukum Prudential, pihaknya telah mengirimkan surat kepada Ketua Pengadilan Niaga Jakarta Pusat untuk mengganti kurator Yuhelson dan mengusulkan Andrey Sitanggang dengan alasan Yuhelson telah mengundurkan diri dari keanggotaan Asuransi Kurator dan Pengurus Indonesia (AKPI) sejak 1 Maret 2002.

Sesuai dengan Pasal 7 Keputusan Menteri Kehakiman No .08-11T.05.10/1998, Yuhelson dianggap tidak memenuhi syarat berpraktek sebagai kurator. Selain itu, ada benturan kepentingan karena sang kurator memiliki hubungan kerja dan/atau afiliasi dengan kuasa permohonan pailit dan pernah bekerja pada kantor pengacara Lucas \& Partners.

Pasal 13 ayat (1) UU Kepailitan menentukan bahwa dalam putusan pailit harus diangkat seorang hakim pengawas yang ditunjuk hakim pengadilan dan kurator. Sementara itu, Pasal 67B ayat (1) menyebutkan bahwa kurator dapat sewaktu-waktu diganti apabila dikehendaki demikian. Pergantian tersebut dapat terjadi atas permintaan kurator sendiri, permintaan kurator lainnya jika ada, usulan hakim pengawas, atau permintaan debitor yang pailit (Hartini, 2002).

Karena itu, langkah yang ditempuh kuasa hukum Prudential untuk mengganti posisi kurator dengan alasan yang dapat dipertanggungjawabkan tidak bertentangan dengan ketentuan perundang-undangan. Pertimbangan mengganti kurator ini tentulah dimaksudkan untuk menjaga kredibilitas kurator agar dalam menjalankan tugasnya bisa bersikap profesional dan tidak memihak.

Secara teknis, pihak yang merasa dirugikan bisa mengajukan permohonan mengganti kurator kepada Ketua Pengadilan Niaga dan atas permohonan tersebut pengadilan memanggil dan meminta penjelasan kurator yang bersangkutan. Apabila permohonan itu dikabulkan, Pengadilan Niaga berwenang mengangkat kurator lain dan/atau mengangkat kurator tambahan.

Bahkan sesuai dengan Pasal 1365 KUH Perdata mengenai perbuatan melawan hukum, kurator dapat digugat untuk bertanggung jawab secara pribadi oleh pihakpihak yang dirugikan atas sikap dan perbuatan kurator. Bahkan kurator harus bertanggung jawab secara pidana atas sikap dan perbuatannya.

Dalam kasus pailit Prudential, alasan yuridis yang digunakan pemohon adalah ketentuan Pasal 1 ayat (1) UU No. 4/1998 jo. Perppu No. 1/1998 tentang Kepailitan yang menyebutkan bahwa "Debitor yang mempunyai dua atau lebih kreditor dan 
tidak membayar sedikitnya satu utang yang telah jatuh waktu dan dapat ditagih dinyatakan pailit dengan putusan pengadilan yang berwenang sebagaimana dimaksud dalam Pasal 2, baik atas permohonannya sendiri maupun atas permintaan seorang atau lebih kreditornya."

Berdasarkan ketentuan tersebut di atas, para pemohon dapat mengajukan permohonan pailit kepada Pengadilan Niaga. Selanjutnya, hakim Pengadilan Niaga yang berwenang mengadili perkara memutuskan apakah suatu perusahaan yang digugat pailit bisa dikabulkan atau ditolak. Sayangnya, dalam berbagai kasus kepailitan, fakta-fakta hukum yang seharusnya menjadi dasar gugatan di pengadilan seringkali dikalahkan karena alasan yang sangat teknis. Inilah sesungguhnya titik lemah yang seringkali dihadapi UU Kepailitan (Hidayah, 2020).

Kasus Prudential Life adalah bukti nyata betapa seorang kreditor memiliki kewenangan yang luar biasa untuk mempailitkan suatu perusahaan yang solid sekalipun. Selain itu, unsur politis juga memainkan peranan yang cukup besar dalam perkara kepailitan, seperti yang dihadapi ketiga hakim yang menyidangkan perkara Manulife--yang berbuntut pada pemberhentian sementara dari jabatannya tanpa alasan yang jelas melalui Keppres No. 139/M/2002 tertanggal 6 Agustus 2002.

Jadi, hampir dapat dipastikan, tidak tertutup kemungkinan hakim yang menyidangkan perkara Prudential Life juga mengalami nasib yang sama. Meski dalam menyidangkan kasus tersebut, kemungkinan terjadinya dissenting opinion dari para hakim bisa saja terjadi. Mudah-mudahan saja pandangan penulis mengenai hal ini keliru.

Perusahaan dapat dinyatakan pailit bila mempunyai hutang jatuh tempo dapat ditagih kepada dua atau lebih kreditor. Undang-Undang No. 4 Tahun 1998 tentang Kepailitan memberi peluang terjadinya pailit semu, artinya faktor kelalaian perusahaan menunaikan kewajiban sesuai perjanjian yang dilakukan, dapat membawanya kepada gugatan secara sepihak memutuskan pailit bagi perusahaan meskipun perusahaan itu sehat secara manajemen dan keuangan, seperti kasus yang terjadi di PT. Prudential Life Assurance.

Kasus ini akhirnya melahirkan amandemen UU Kepailitan yang kemudian disahkan menjadi UU No. 37/2004 tentang Kepailitan dan Penundaan Kewajiban Pembayaran Utang (UUK-PKPU). Dalam UUK-PKPU terdapat ketentuan bahwa ketika debitor adalah perusahaan asuransi atau reasuransi, maka pengajuan permohonan pailit dilakukan oleh Menteri Keuangan.

Setelah berlakunya UU No. 40 Tahun 2014 tentang Perasuransian (UU Perasuransian) yang mengatur bahwa permohonan pernyataan pailit dan PKPU terhadap perusahaan asuransi beralih kepada dan hanya dapat diajukan oleh Otoritas Jasa Keuangan (OJK), penegasan tersebut diatur dalam:

- Pasal 55 ayat (1) UU No. 21 Tahun 2011 tentang Otoritas Jasa Keuangan (UU OJK)

- Pasal 50 ayat (1) UU Perasuransian 
- Keputusan Ketua Mahkamah Agung No. 109 Tahun 2020 (Buku Pedoman Penyelesaian Perkara Kepailitan dan PKPU)

Aset yang dikelola perusahaan asuransi yang berpusat di Inggris ini nilainya triliunan, bahkan, pada tahun 2003 mereka berhasil membukukan kenaikan premi lebih dari Rp1 triliun. Selain menyatakan Prudential pailit, dalam amar putusannya, majelis hakim juga mengangkat Yuhelson dan Binsar Siregar masing-masing sebagai kurator dan hakim pengawas. Perlu pula disampaikan, berdasarkan catatan hukumonline, Yuhelson adalah mantan lawyer di kantor pengacara Lucas SH \& Partners. Sementara, yang menjadi kuasa hukum Lee Boon Siong di kasus ini juga Lucas SH \& Partners.

Direksi tidak berwenang, Yuhelson mengatakan baru mendengar putusan ini. Ia belum bisa menjelaskan langkah-langkah yang akan ia ambil selaku kurator Prudential karena belum menerima salinan putusan hari ini. Namun ia menegaskan, bahwa berdasarkan Undang-undang Kepailitan, putusan pailit ini mengakibatkan jajaran direksi Prudential tidak lagi memiliki wewenang untuk mengambil tindakan apapun. Pasalnya, kewenangan itu telah beralih kepada kurator. Kendatipun demikian, Yuhelson menegaskan bahwa ia akan berkoordinasi terlebih dahulu dengan hakim pengawas sebelum mengambil langkah hukum. Kita akan persuasif dulu, ujar Yuhelson.

Sebagaimana telah diberitakan dalam permohonan pailit yang didaftarkan di Pengadilan Niaga Jakarta Pusat pada 25 Maret lalu, Lee mengklaim kepada Prudential bahwa dirinya berhak mendapatkan bonus pencapaian target, bonus rekruitmen dan bonus konsistensi yang nilainya jika diakumulasikan lebih dari Rp5,7 miliar. Lee juga menagih ongkos perjalanan sebesar Rp130 juta, yang menurutnya menjadi kewajiban Prudential. Lee juga mengklaim ia berhak menagih pelunasan kewajiban Prudential, berdasarkan Pasal 129 dan 259 Undang-undang Kepailitan (UUK). Artinya, Prudential harus membayar angsuran bonus kepada Lee sampai tahun 2013 yang jumlahnya lebih dari Rp360 miliar (Tempo.com, 2004).

Dengan berlakunya Undang-Undang No.37 Tahun 2004 tentang Kepailitan dan Penundaan Kewajiban Pembayaran Utang (UUK-PKPU), hanya Menteri Keuangan yang dapat mengajukan kepailitan terhadap perusahaan asuransi. Undang-undang tersebut menghapus ketentuan Undang-undang lama (Undang-Undang No.4 Tahun 1998 (UUK) yang memperbolehkan kreditor untuk secara langsung dapat mengajukan permohonan kepailitan perusahaan asuransi. Pengadilan Niaga dapat mempailitkan perusahaan asuransi atas permohonan yang diajukan Menteri Keuangan jika syarat-syarat untuk menjatuhkan kepailitan terpenuhi, yaitu berdasarkan Pasal 2 ayat (1). Kewenangan Menteri Keuangan dalam Pasal 2 ayat (5) UUK-PKPU yang diberikan oleh pembentuk Undang-undang hanya menyangkut kedudukan hukum (Legal Standing). Menteri Keuangan sebagai pemohon dalam perkara kepailitan karena fungsinya sebagai pemegang otoritas di bidang keuangan dan sama sekali tidak memberikan keputusan yudisial yang merupakan kewenangan Hakim. Kewenangan yang diberikan oleh pembuat Undang-undang terhadap instansi 
yang berada di lingkungan eksekutif itu bukan merupakan wewenang mengadili (yustisial).

Sutan Remy Sjahdeini berpendapat bahwa seyogianya hak untuk mengajukan permohonan pailit terhadap suatu perusahaan asuransi tidak menjadi monopoli Menteri Keuangan saja, apabila Menteri Keuangan terlibat dalam putusan-putusan pernyataan pailit, yaitu supaya suatu perusahaan asuransi tidak mudah dipailitkan mengingat kepentingan para pemegang polis asuransi yang demikian banyak, dapatlah dipertimbangkan permohonan pernyataan pailit apabila terhadap permohonan pailit itu telah diperoleh persetujuan dari Menteri Keuangan. Dengan, demikian, hak untuk mengajukan permohonan pernyataan pailit bukan merupakan monopoli Menteri Keuangan yang hanya akan memasung hak kreditor dan debitor serta Kejaksaan untuk mengajukan permohonan pernyataan pailit suatu perusahaan asuransi. Pengajuan permohonan pernyataan pailit berdasarkan kepentingan umum terhadap suatu perusahan asuransi seyogianya dapat pula diajukan selain oleh Kejaksaan, Menteri Keuangan atau nantinya oleh Otoritas Jasa Keuangan, yaitu sebagai lembaga independen yang ditugasi mengawasi lembaga-lembaga keuangan termasuk perusahaan-perusahaan asuransi (Sjahdeini \& Manan, 2002).

\section{Kesimpulan}

Undang-Undang No.4 Tahun 1998 tentang Kepailitan memberi peluang terjadinya pailit semu, artinya faktor kelalaian perusahaan menunaikan kewajiban sesuai perjanjian yang dilakukan dapat membawa kepada gugatan secara sepihak memutuskan pailit bagi perusahaan itu, meskipun perusahaan itu sehat secara manajemen dan keuangan seperti kasus yang terjadi di PT. Prudential Life Assurance.

Kasus ini akhirnya melahirkan amandemen UU Kepailitan yang kemudian disahkan menjadi UU No. 37/2004 tentang Kepailitan dan Penundaan Kewajiban Pembayaran Utang (UUK-PKPU), yang di dalamnya terdapat ketentuan bahwa ketika debitor adalah perusahaan asuransi atau reasuransi, maka pengajuan permohonan pailit dilakukan oleh Menteri Keuangan.

Bertitik tolak dari permasalahan dan berdasarkan analisis di atas, dapat disimpulkanbahwa : Utang dalam UUK-PKPU telah diberi pengertian secara jelas dan luas, yaitu utang tersebut tidak hanya berupa kewajiban yang timbul dari perjanjian, melainkan juga kewajiban-kewajiban lain yang menimbulkan kewajiban untuk memberikan sesuatu atau untuk tidak berbuat sesuatu. Sehingga Putusan Kasasi Mahkamah Agung tersebut sudah sesuai dengan UUK-PKPU dimana definisi utang menurut yurisprudensi tersebut berlaku juga untuk kepailitan perusahaan asuransi, sehingga semua utang tersebut dapat menyeret perusahaan asuransi untuk dipailitkan. Pihak kreditor hanya dapat mengajukan permohonan pailit perusahaan asuransi tersebut hanya melalui Menteri Keuangan dengan atau tanpa permohonan dari para kreditor, apabila perusahaan asuransi tersebut dipandang melanggar ketentuan-ketentuan perundang-undangan perasuransian dan merugikan para pemegang polis.

Namun setelah berlakunya UU No. 40 Tahun 2014 tentang Perasuransian (UU 
Perasuransian), permohonan Pernyataan Kepailitan dan PKPU terhadap perusahaan asuransi beralih dari kewenangan Menteri Keuangan kepada Otoritas Jasa Keuangan (OJK).

Baik putusan pailit terhadap Perusahaan Asuransi Jiwa Manulife Indonesia berdasarkan Putusan No. 10/Pailit/2002/PN.Niaga.Jkt.Pst jo.Putusan MA No. 021/K/N/ 2002, maupun putusan pailit terhadap Perusahaan Asuransi PRUDENTIAL LIFE ASSURANCE berdasarkan Putusan No. 13/Pailit/ 2004/PN.Niaga. Jkt.Pst jo. Putusan Nomor : 08/K/N/2004, adalah sama-sama putusan pailit yang diajukan oleh kreditor berdasarkan kewenangannya sesuai ketentuan dalam Undang-Undang No. 4 Tahun 1998 tentang Kepailitan.

Sejak disahkannya UU No. 37/2004 tentang Kepailitan dan Penundaan Kewajiban Pembayaran Utang (UUK-PKPU), UU No. 21 Tahun 2011 tentang Otoritas Jasa Keuangan (OJK) dan UU No. 40 Tahun 2014 tentang Perasuransian, maka pengajuan Permohonan Pernyataan Pailit terhadap perusahaan Asuransi , kewenangannya beralih dari Menteri Keuangan menjadi kewenangan oleh Otoritas Jasa Keuangan (OJK), sebagaimana dimaksud Pasal 5 O ayat (1) UU No. 40 Tahun 2014 tentang Perasuransian, yaitu : Permohonan pernyataan pailit terhadap Perusahaan Asuransi, Perusahaan Asuransi Syariah, perusahaan reasuransi, atau perusahaan reasuransi syariah berdasarkan Undang-Undang ini hanya dapat diajukan oleh Otoritas Jasa Keuangan. 


\section{BIBLIOGRAFI}

Amiruddin \& Asikin, Z. (2004). Pengantar metode penelitian hukum. Jakarta: Raja Grafindo Persada. Google Scholar

Fuady, M. (1999). Hukum pailit 1998: dalam teori dan praktek. Citra Aditya Bakti. Google Scholar

Ginting, E. R. (2018). Hukum Kepailitan: Teori Kepailitan. Bumi Aksara. Google Scholar

Hartini, R. (2002). Hukum kepailitan. Pembinaan Penelitian dan Pengabdian Masyarakat. Google Scholar

Hidayah, N. P. (2020). Hukum Acara Peradilan Niaga Mengupas Sengketa Kepailitan, PKPU dan Kekayaan Intelektual (Vol. 1). UMMPress. Google Scholar

Indonesia. (2004). Undang-Undang Republik Indonesia nomor 37 tahun 2004 Tentang Kepailitan dan Penundaan Kewajiban Pembayaran Utang. Direktorat Jenderal Peraturan Perundang-Undangan, Departemen Hukum dan HAM RI. Google Scholar

Kementrian Keuangan Republik Indonesia. (2020). Kepailitan dan Akibat Kepailitan Terhadap Kewenangan Debitur Pailit Dalam Bidang Hukum Kekayaan. Www.Djkn.Kemenkeu.Go.Id.

https://www.djkn.kemenkeu.go.id/artikel/baca/13451/Kepailitan-dan-Akibat-

Kepailitan-Terhadap-Kewenangan-Debitur-Pailit-Dalam-Bidang-Hukum-

Kekayaan.html. Google Scholar

KoranTempo. (2004). Skandal Pailit Manulife dan Prudential, Rusmin EffendyMantan Konsultan Hukum Manulife dan Direktur Eksekutif Lembaga Strategis Kajian Demokrasi dan Politik Indonesia. Google Scholar

Moneta, V. (2004). Kasus Kepailitan PT Prudential. Academia.

https://www.academia.edu/25568444/Kasus_Kepailitan_PT_Prudential. Google

Scholar

Nindyo Pramono, S. H., \& Sularto, S. H. (2017). Hukum Kepailitan dan Keadilan Pancasila-Kajian Filsafat Hukum atas Kepailitan Badan Hukum Perseroan Terbatas di Indonesia. Penerbit Andi. Google Scholar

Prudential.co.id. (1995). Tentang Prudential Indonesia. Prudential.Co.Id. https://www.prudential.co.id/id/about-prudential-indonesia/. Google Scholar

Purwosutjipto, H. M. N. (1988). Pengertian Pokok Hukum Dagang Indonesia 8: Perwasitan, Kepailitan Dan Penundaan Pembayaran. Google Scholar 
J.B. Budhisatrio, Dhaniswara K Harjono, Binoto Nadapdap

Situmorang, V. M., \& Soekarso, H. (1994). Pengantar Hukum Kepailitan di Indonesia. Rineka Cipta. Google Scholar

Sjahdeini, S. R., \& Manan, B. (2002). Hukum kepailitan: memahami faillissementsverordening juncto Undang-Undang no. 4 tahun 1998. Grafiti. Google Scholar

Tempo.com. (2004). Pemerintah Siapkan Penyelesaian Kasus Prudential. Bisnis.Tempo.Co. https://bisnis.tempo.co/read/42089/pemerintah-siapkanpenyelesaian-kasus-prudential. Google Scholar

\section{Copyright holder:}

J.B. Budhisatrio, Dhaniswara K Harjono, Binoto Nadapdap (2021)

First publication right:

Jurnal Syntax Admiration

This article is licensed under:

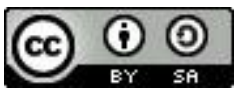

